\title{
Sustainability of tropical small-scale fisheries: Integrated assessment in French Guiana
}

\author{
Abdoul Ahad Cissé $^{\mathrm{a}, \mathrm{b}, *}$, Fabian Blanchard ${ }^{\mathrm{a}}$, Olivier Guyader ${ }^{\mathrm{c}}$ \\ a IFREMER, Domaine de Suzini, BP 477, 97331 Cayenne, French Guiana, France \\ ${ }^{b}$ CEREGMIA, University of the French West Indies and French Guiana, BP 266, 97326 Cayenne, French Guiana, \\ France \\ c IFREMER, UMR AMURE, Département d'économie maritime, Centre de Brest, BP 70, 29280 Plouzané, France \\ *: Corresponding author : Abdoul Ahad Cissé, tel.: +59405943022 00 ; fax: +594 594308031 ; \\ email address : abdoul.cisse@ifremer.fr
}

\begin{abstract}
:
Like many tropical small-scale fisheries, the French Guiana coastal fishery is characterized by the high fish biodiversity of its ecosystem, the weak selectivity of the fleets exploiting the resources, and the heterogeneity of the vessels in terms of size and fishing techniques. The Rapfish method is used to assess sustainability within 11 fishery systems by means of 27 attributes relating to ecological, economic, social, and technological fields. Overall results indicate an average performance in the weak sustainability range. Comparisons made among the FSs show a gradient of sustainability performance from the western portion of the coast to the eastern portion. Several recommendations are formulated to raise the current "sustainability" status, such as the reduction of discards. This study is used as a complementary tool to the bioeconomic model in order to define a sustainable management plan for the French Guiana coastal fishery.
\end{abstract}

\section{Highlights}

Sustainability of French Guiana coastal fishery is analyzed using Rapfish method. Sustainability is evaluated in a multidimensional framework. Within the fishery, production systems present different performance levels. A gradient of sustainability appears from the west to the east. Strong sustainability concept is more functional for identifying potential issues.

Keywords : French Guiana ; Small scale fishery ; Sustainability ; Rapfish ; Ecosystem approach 


\section{Introduction}

The traditional tools used to manage fisheries are more suitable for homogeneous fleets targeting one species $[1,2]$. Simple catch and effort data are no longer sufficient to satisfy the interests of the different stakeholders, and the need to improve knowledge about small-scale fisheries in order to secure their sustainable development is increasingly recognized [3-6]. The necessity of taking an integrated approach to tackling sustainability issues in a complex framework is now acknowledged [7, 8]. However, there is a lack of operational methodology to assess and manage heterogeneous small-scale fisheries that exploit multiple species, despite their socio-economic importance, especially in developing countries, and that would also take into account an ecosystem approach.

Among the techniques that aim to achieve an integrated assessment of fisheries, the Rapfish method [9] is well ranked [8] and appears to be the most suitable, since it takes into account the multidisciplinary endeavor in fisheries in addition to ecological considerations. This method provides a rapid assessment of fishery status and does not require extensive data. It relies upon the ordination of scored attributes grouped in ecological, economic, social, and technological sustainability fields achieved by using multidimensional scaling (MDS) including uncertainties. The ability of Rapfish to assess sustainability status has been largely tested on fisheries worldwide (see official Rapfish website for more details ${ }^{1}$ ). More recently, this technique has been used in several tropical coastal fisheries in Brazil [10 - 14].

In the disciplinary field of economics, the substitutability between environmental assets and human-made capital is debated in the context of ecological and resource economics [15]. According to neoclassical economists, ecological decline can be compensated for by maintaining the overall welfare of society. This is the so-called weak sustainability approach. However, in the long term, "ecological decline" (depleted stocks, species loss, habitat alteration, etc.) drives the alteration of goods and services provided by ecosystems such as income from exploitation, which in turn no longer enable the welfare of society to be maintained. In the same way, but in the disciplinary field of fisheries science, defining the maximum biological sustainable yield (MSY) has been the basis of fisheries management. Since the effects of fishing on ecosystems were ignored, as well as the economic viability of the fisheries, this is also a weak sustainability approach. Actually, it has now been recognized that a systemic approach is necessary, because the exploited resources and the fisheries exploiting them depend on socio-ecological interactions. Thus there is nowadays widespread acceptance that a more integrated perspective is needed that would take both marine biodiversity preservation and economic and social objectives into account. In this context, the Ecosystem Approach has emerged as a promising approach. The strong sustainability paradigm [16, 17], which allows no substitutability between different types of "capital" (natural or human-made), therefore seems more consistent. The diagnosis provided here via an assessment carried out using the Rapfish method explicitly takes into account several dimensions such as natural and human-made capital.

\footnotetext{
${ }^{1}$ http://www.rapfish.org
} 
The French Guiana coastal fishery has been neglected as it serves exclusively to supply local food demand. Moreover, this fishery is quite complex, with various landing sites and numerous species exploited, and is partially informal. With the decline of the shrimp fishery, the great potential of this fishery has been revealed [18]. In fact, the coastal fishery has yielded more than the shrimp and red snapper fisheries since 2008. The coastal fishery has been monitored for 6 years, but no stock assessment has been carried out so far. Nevertheless, the biodiversity associated with this resource does not seem to be threatened by fishing activities, as yields seem stable up to 2010. Still, fish yields are not the same in all the fishing areas. Recent socio-economic studies highlight the difficulties of some fleets to generate profits, mainly because of the low selling prices and high and fluctuating input costs such as fuel. The total population of French Guiana is around 250,000, and demographic projections show it will double over the next 20 years, thus raising the issue of fish demand fulfillment. More generally, the value of carrying out an integrated assessment, taking into account all dimensions, had never been examined before. In this paper, the sustainability of the French Guiana coastal fishery according to ecological, economic, social, and technological dimensions is diagnosed using the Rapfish method. Important sustainability-related factors requiring improvement are also identified.

The paper is structured as follows: Section 2 presents the French Guiana coastal fishery in more detail. Section 3 provides insights on the data used and the Rapfish methodology. Section 4 is devoted to depicting the results for each dimension. Findings are discussed in Section 5 and the last section draws a conclusion.

\section{Case study}

The continental shelf of French Guiana is a tropical ecosystem under the influence of the Amazon estuary, as is the entire North Brazil Shelf Large Marine Ecosystem (LME), which has a high level of biodiversity [19]. With a $350 \mathrm{~km}$ coastline, French Guiana benefits from a $130,000 \mathrm{~km}^{2}$ Exclusive Economic Zone (EEZ) including $50,000 \mathrm{~km}^{2}$ of continental shelf, bordered in the west by Suriname and in the east by Brazil. The coastal fishery operates in a $16 \mathrm{~km}$ offshore zone with depths from 0 to $20 \mathrm{~m}$; fishing areas are close to the landing points. The eight main landing points are spread out along the coastline. The major landing point, Cayenne, receives one third of the total annual landings, which are estimated at around 3,000 tons per year and are increasing as reported in the Ifremer $^{2}$ data collection (http://www.ifremer.fr/guyane/Chiffres-cles).

This fishery currently involves approximately 200 wooden boats that are less than 12 meters long. Traditionally, four kinds of vessel are identified [20]: Pirogues (P), Canots créoles (CC), Canots créoles améliorés (CCA) and Tapouilles (T). Pirogues, which are canoes equipped with an outboard engine, fish for a few hours essentially in estuaries using stored ice in an old refrigerator. Compared to Pirogues, Canots créoles are better suited to sea navigation. Canots créoles améliorés have cabins and ice tanks, which enable them to fish for

\footnotetext{
${ }^{2}$ French Research Institute for Exploitation of the Sea.
} 
several days. Tapouilles are wider boats with a cabin and an inboard diesel engine. Catches are conserved on ice and trips last up to 10 days. Even if some fishermen use several types of gear including long lines and hooks, the main gears used are drift or fixed nets, with mesh sizes between 40 and $100 \mathrm{~mm}$. The fleets have a limited range and operate in different fishing areas.

More than 30 coastal species are exploited and about 15 species, including weakfishes, catfishes, and sharks, represent more than $90 \%$ of the production. The dominant species landed is the Acoupa Weakfish (Cynoscion acoupa), representing around $40 \%$ of total landings, followed by the Green Weakfish (Cynoscion virescens) and the Crucifix Catfish (Sciades proops) with respectively $13 \%$ and $11 \%$.

Since it operates in an overseas region of the EU, the French Guiana coastal fishery is governed by French and European regulations through technical measures (maximum net length, minimum mesh size, and marine protected area) and access regulation (European authorization and regional licenses). Despite this, an important part of this fishery remains informal, as one third of the active vessels do not have a permit. There are no quotas for catches, and no limitation concerning exploited species and their size. The French Guiana coastal fishing area is also illegally exploited by Brazilian and Surinamese fleets. Foreign illegal catches are estimated to be at least twice as large as those of French Guiana [21].

\section{Materials and methods}

a. Data collection

With the observation system implemented by Ifremer since 2006, production and fishing effort values are collected on a daily basis at the main landing points by observers from local communities. It is possible to carry out an exhaustive observation of the fishing effort thanks to the small number of active boats (approximately 200). The landings of seventy five percent (75\%) of the fishing activity are observed on a daily basis from January to December. Each year, some 3,600 landings are recorded. For each landing, the production by species is either estimated by the observers or reported by the fishermen. Other information is also collected, such as trip length, net length, fishing area, number of crew, quantity of ice, and fuel consumed. For this study, data from 2006 to 2009 were used.

Two socio-economic surveys were carried out in this fishery in 2009 and 2011. Only vessels with significant fishing effort were sampled. The objective was to obtain economic data from a sample of vessels representative of the different segments. The sampling strategy used for vessel sampling selection was similar to that developed for mainland France [22]. The questions were based on a monetary approach that also includes social indicators. The questionnaire consisted of nine main sections presented in a logical order; surveys were conducted with vessel owners on their fishing activities, related earnings and costs, and more specifically, on the characteristics of their fishing vessel. The latter include the type of hull, engine, fishing gear, electronic equipment, and related costs. The survey also included questions about family implication in fishing activities, fishermen educational level, conflicts, 
and discards. Technical documents (in French) describing the methodology, from sampling optimization to the questionnaire, and the software used to record the information collected are available on the Ifremer website (http://www.ifremer.fr/sih/). Around $40 \%$ of the active boat owners were questioned. The socio-economic surveys and the regular data collection concern both the legal and illegal coastal vessels of the fishery.

Data collected from the economic survey were validated vessel by vessel and variable by variable in several stages, including tests on quality, consistency, and continuity between variables. All economic variables were compiled in accordance with the definitions in Appendix VI of EC [23].

\section{b. Selection of FSs}

To address the spatial distribution of the fleets and their heterogeneity, the French Guiana coastal fishery was split into 11 Fishery Systems (FS) according to landing site and vessel type (Table 1), since they all use nets and none of them target a specific species. The fishing areas of the FSs are distinct, as the landing sites are distant from each other and the types of vessel allow them to operate more or less close to the coast.

Table 1 about here.

\section{c. Choice of attributes and scoring}

An attribute is a characteristic that quantitatively describes a fishery system and should reflect sustainability within each dimension [9]. To adapt the Rapfish analysis to the present case study, attributes were chosen from different sources [9-12]. For each FS, 50 attributes corresponding to 6 dimensions (ecological, economic, social, technological, ethical, and management) were pre-selected. In concordance with Pitcher and Preikshot [9], 23 attributes and 2 dimensions were removed from the analysis since attributes must be easily and objectively scored and data used to score each chosen attribute must be available for each FS. Data used to score the attributes were all quantitative. Each attribute was scaled and values were specified for each FS. The scale system used is that of the "Standard attributes" proposed by the Rapfish Group of the University of British Colombia's Fisheries Centre. Attributes and scoring criteria are shown in Table 2.

Table 2 about here.

\section{d. Analysis}

To perform the Rapfish analysis, the "add-in" for Microsoft's Excel ${ }^{4}$ is used, as described in Kavanagh and Pitcher [24]. Rapfish uses a statistical ordination technique, Multidimensional

\footnotetext{
${ }^{3}$ Standard attributes refer to those revised by the Rapfish Group, Fisheries Centre, UBC and downloaded in July 2011 from the website "http://www.rapfish.org".

${ }^{4}$ This "add-in" can be downloaded from the Rapfish official website "http://www.rapfish.org".
} 
Scaling (MDS), to reduce the NxM matrix of fisheries $(\mathrm{N})$ and attributes (M) to generate a $\mathrm{Nx} 2$ dimensional space that represents the sustainability of each FS along a scale from $0 \%$ to $100 \%$. The "good" fishery (100\% sustainability score) represents the best possible score, while the "bad" fishery ( $0 \%$ sustainable score) stands for the worst score for all the attributes. Additional fixed reference points, expressing two half-way scores, are included in the ordination to ensure that new evaluations do not flip vertically to their mirror, as well as random reference points ("anchor" fisheries) added to "minimize shifts when overlaying points from different analyses". Attribute scores were normalized so that they all have equal weight in the analysis. The "stress" values indicate the quality of the ordination (values below 0.25 are considered acceptable [9]).

Uncertainty is expressed for each evaluation field using Monte Carlo sampling from a normal distribution with a $95 \%$ confidence interval. Five hundred runs were made and the median as well as the $50 \%$ interquartile range of the scatter provided upper and lower extreme values for each attribute [24]. A leverage analysis was performed to identify the different attributes that had proportionally the largest influence on the results. This was done by dropping each attribute sequentially from the MDS analysis.

\section{Results}

Fig. 1 shows two dimensional plots for the status results from the MDS ordinations. The fisheries are spread out along the $\mathrm{X}$-axis according to their relative sustainability in each evaluation. The vertical distribution of the fisheries on the Y-axis expresses differences not related to sustainability. Fig.2 shows the different FS scores in order of performance rating in each dimension (X-axis, Fig.1). Following Pitcher et al. [25], scores over 70\% are considered "good" and the FS may be reasonably regarded as sustainable in the corresponding evaluation field. Scores over $60 \%$ but under $<70 \%$ are considered "acceptable" but in need of improvement, while ratings of $40 \%$ and less depict a "failing grade" in terms of sustainability.

Fig. 1 about here.

Fig.2 about here.

Kurkal's stress and RSQ show good ordination for all evaluations ("Stress" $<0.25$ ) except for the technological dimension (Table 3). Fig.3 illustrates the leverage of individual attributes. Concerning the ecological analysis, the attributes that influence the ordination position most are "trophic level" and "discards" with standard error (S.E.) respectively about $6.8 \%$ and $6.7 \%$. The leverage of other attributes stands between $1.6 \%$ and $5.2 \%$. In the economic dimension, the leverage shows greater homogeneity, with leverage ranging from $1.2 \%$ to $3.4 \%$. Regarding the social dimension, the "origin of fishermen" attribute has the highest influence (S.E about 4.4\%), followed by "healthcare" and "kin participation, with $4.3 \%$ and $4.1 \%$ respectively. The lowest values of attribute leverage are observed in the technological 
ordination with leverage ranging from $1 \%$ to $3 \%$ (S.E). No attribute dominates in this analysis since they all have leverage below $10 \%$ [26].

Table 3 about here.

Fig. 3 about here.

\section{a. Ecological dimension}

In the two-dimensional ordination plot of the ecological field (Fig.1-a), the FSs are relatively clumped together. Ecological performances range on average from $52.8 \%$ to $67.3 \%$. The FS with the lowest score in the ecological evaluation is "C_T" (FS n 7 in Fig. 1-a) made up of the Tapouille fleet and landing in Cayenne. Only 3 FSs have the uppermost confidence limits surpassing the "good" $70 \%$ threshold, and 8 FSs have the lowest confidence limits below the "acceptable" 60\% score (Fig.2-a).

\section{b. Economic dimension}

FSs are more spread out in the two-dimensional economic ordination (Fig.1-b). The economic performance scores rank on average from $38.3 \%$ to $67.1 \%$. The FS with the lowest score in the economic evaluation is "SG_CC" (FS n'11 in Fig.1-b) made up of the Canot créole fleet and landing in Saint Georges. The first 4 FSs in this dimension are "SI_CC", "SL_CC", "K_CC", and "A_P", made up of the Canot créole and Pirogue fleets. Only one FS has the highest confidence limits over the "good" $70 \%$ threshold, and 9 FSs have the lowest confidence limits below the "acceptable" 60\% score (Fig.2-b).

\section{c. Social dimension}

The two-dimensional social ordination (Fig.1-c) does not show any particular FS cluster. The social performance scores range from $42.1 \%$ to $66.1 \%$. The best FS in the social evaluation is "C_T" (FS n ${ }^{\circ} 7$ in Fig.1-c) made up of the Tapouille fleet and landing in Cayenne. "C_T" holds the highest confidence limits beyond the "good" $70 \%$ threshold and the other FSs have the lowest confidence limits below the "acceptable" 60\% score (Fig.2-c).

\section{d. Technological dimension}

FSs clump together much more in the two-dimensional technological ordination as shown in Fig.1-d. Technological performance scores range from $50.2 \%$ to $56.6 \%$, and no FS reaches the "acceptable" $60 \%$ threshold. The worst FS in the technological evaluation is "C_T" (FS $\mathrm{n}^{\circ} 7$ in Fig.1-d). No FS holds the highest confidence limits spanning the "good" $70 \%$ threshold, but four of them are above the "acceptable" 60\% score (Fig.2-d). All FSs have the lowest confidence limits below the "acceptable" 60\% score (Fig.2-d).

\section{e. Comparisons between fishery systems}

According to Fig.4, which presents the overall sustainability performance of each FS, the FS made up of the "P" fleet is better ranked, followed respectively by FSs with "CC", "T", and 
"CCA" fleets. Six FSs have an overall score with the uppermost confidence limits over the "acceptable" $60 \%$ boundary. This pattern is confirmed by Fig. 5-b where FSs grouped by fleet type show "acceptable" performance for the "P", "CC", and "T" fleets. Fig. 5-a showing the overall performances of FSs regrouped by geographical area reveals that FSs in the western portion of the coast are more efficient, followed by those in the middle and eastern portions of the coast. The western and middle portions present overall scores above the "acceptable" $60 \%$ threshold.

Fig.4 about here.

Fig.5 about here.

\section{Discussion}

a. Ecological dimension

The clustering of the FSs in the ecological field is not surprising, as the FSs actually operate in the same ecosystem and fishing areas are at most $350 \mathrm{~km}$ distant from each other. Moreover, the FSs exploit the same set of species using the same fishing technique (drift net). The recruitment variability, calculated according to production, is low and nearly identical except for "SL_CC" and "SG_CC", for which the fishing areas are located in the border zone with Suriname and Brazil. The "trophic level" is relatively high, around 4, for all FSs, and there have been no significant changes within it for the last few years.

The "CC_T" presents the lowest rate in this evaluation field. In fact, this FS, made up of the Tapouille fleet, is an ecological underachiever in terms of discards. This FS targets acoupa species in particular and the rate of discards is high: around $50 \%$ of the catches are thrown overboard. Note that the two most highly rated FSs in this evaluation field are "C_CC" and "A_P", for which the rate of discards is nil. The pressure on the ecosystem from "P" and "CC" fleets is low because they fish partly for subsistence and their catch capacity is limited.

\section{b. Economic dimension}

The dispersion of the FSs in the two-dimensional economic ordination (Fig.1-b) reveals the high discrimination power of the economic dimension attributes. The four FSs presenting the best scores in this evaluation field are those with the highest rate of profitability. In fact, since fishers in these FSs sell directly to the consumer in local markets, they have the highest selling price. It should be noted that the average fish price in French Guiana is much lower than in the other French territories. Since the fleets are small and artisanal, equipment costs are lower. A large proportion of fishers in these FSs has a second job and earns more than the minimum legal salary. The level of subsidies in these FSs is low due to their distance from the main government agencies, their lack of organization, and the fact that they are not registered in the national data base of legal fleets. In addition, "P" fleets and some "CC" fleets are often informal, so they do not pay taxes. Therefore, if they were formal, their economic performance would be lower. 
The worst performing FS in the economic field, "SG_CC", is located in a town on the border with Brazil. The small size of the local market in this town leads the fishers to sell the greater part of their product to Brazilian middlemen at low prices. Due to the lack of facilities, "intermediate consumption" costs (ice, fuel, etc.) are very high. Activities in this FS are often unprofitable. The other FSs have the highest activity and production per year but depend exclusively on middlemen for the selling process. For these FSs, the share of equipment costs out of total income is the largest, around $25 \%$.

\section{c. Social dimension}

Performances of FSs in this social field reveal their heterogeneity. "C_ T", which presents the highest scores, exhibits a high educational level compared to the French Guiana population. This FS is not in conflict with other resource users, fishers of this FS have good access to healthcare, and finally, this FS is the most highly rated in terms of "kin participation". The lowest rated FSs in the social dimension, "SI_CC" and "SI_CCA", exhibit the poorest performance in the following attributes: conflict status, healthcare, residence quality, and origin of fishermen. In fact, these FSs are distant from healthcare centers; the fishermen are largely from border countries (Guyana), and they live on the boat at the dock. These FSs are often in conflict with other users. It should be noted that even though the boats ${ }^{\text {ee }}$ owners are from the local population, more than $90 \%$ of the fishermen are foreigners. The hard working conditions and the low level and variability of earnings discourage the local population.

\section{d. Technological dimension}

Unsurprisingly, the FSs exhibit approximately the same performance in the technological field. Indeed, the technology used in the different FSs is relatively similar. They use drift or fixed nets and vessels between 7 and 12 meters long with motors. All FSs process the fish before storing them on ice, and the minimum mesh size $(40 \mathrm{~mm})$ is usually respected. "C_T", the FS presenting the lowest performance, uses the largest boat with the largest engine power and has the longest trip length.

\section{e. Comparisons between fishery systems}

It is argued in the introduction section that the strong sustainability approach was developed here as more appropriate in the context of an ecosystem approach. Moreover, in terms of recommendations for policy making pertaining to ecological, social, economic, and technological issues, improvements were necessary for each of the dimensions in order to increase the sustainability of these fisheries. From a weak sustainability perspective, all the FSs (except one) are sustainable (Table 4). However, this is not the case with a strong sustainability approach: according to the scores on the economic and social dimensions, six FSs out of eleven are not sustainable, with scores below 50 (Table 4).

Table 4 about here.

If the weak sustainability approach may not be appropriate in the ecosystem approach and for policy making, it can, however, be useful for comparing fisheries [27]. The aggregation of the 
FS performance results reveal two clear patterns: (i) by fleet, the gradient of sustainability runs from top to bottom: "P" fleet, followed by "CC", "T", and "CCA"; (ii) by area, a gradient of sustainability appears from the western portion of the coast to the eastern portion. In fact, FSs in the west are made up of "P" and "CC", which are the most efficient (Fig.5-b), while "T", "CCA", and "CC" form the FSs in the middle portion of the coast. The eastern portion of the coast being the less sustainable area is made up of only the "SG_CC" FS. This FS ranked in the last four places in all evaluation fields. In particular, it exhibits the worst performance in the economic field.

The kite diagrams resulting from the combination of all the Rapfish analysis fields are available in Fig.6 whereas FSs are aggregated by area and fleet type. FSs in the western portion of the coast reveal the best performances in all evaluation fields. FSs in the middle and eastern portions of the coast are less efficient, essentially in the economic and social dimensions (Fig.5-a). In all dimensions, "P" presents the best performances except for the social evaluation field, in which the "T" fleets are the best (Fig.6-b). Conversely, the "CCA" fleet appears to be the least sustainable (Fig.5-b), particularly in the economic and social fields (Fig.6-b). The "T" has the worst results in the ecological and technological fields. Although the "T" and "CC" fleets seem to have the same overall performances in terms of sustainability, it is important to note that this is only due to the "good" results of the "T" fleet in the social field, which compensate for their performances in the other dimensions, indicating low multidimensional sustainability. However, no relationship between high educational level and overfishing can be established for the " $\mathrm{C}_{-} \mathrm{T}$ " system. The low performances in the ecological and technological fields of this FS are mostly explained by the poor scores for the attributes pertaining to discards, trophic level, size of species, trip length, and selectivity, attributes for which the analysis is sensitive (Fig.3). The good score of this FS in the social dimension is due to its good rating for the attributes relating to conflict status, kin participation, and healthcare. This FS does not interact with the other FSs, as their fishing areas are different, thus conflicts are limited. Furthermore, family implication is significant and the fishermen have easy access to healthcare, as this FS is based in the main city in French Guiana. The " $\mathrm{C}_{-} \mathrm{T}$ " system, using " $\mathrm{T}$ " fleet, is market-oriented, intensive, and more ecologically aggressive, but its fishermen have the best living conditions.

Fig.6 about here.

\section{Conclusion}

This paper contributes to enhancing knowledge about the French Guiana coastal fishery, which has been neglected compared to other fisheries. The sustainability of the French Guiana coastal fishery is analyzed through 11 identified fishery systems, using the Rapfish methodology. Considering that substitutability among different dimensions is not consistent with the ecosystem approach, the sustainability of FSs is evaluated in a multidimensional framework (ecological, economic, social, and technological). The analysis of sustainability is strongly affected by the choice of attributes. However, the resulting analysis is only indicative of the relative sustainability of FSs, although it provides relevant and useful information for 
stakeholders and helps determine where interventions are most needed [28]. In fact, the benefit of weak sustainability is limited if an ecosystem approach to fisheries is adopted and may only be useful for the comparison of sustainability between fisheries. In contrast, as pointed out by other articles [27], the strong sustainability concept together with the definition of critical thresholds is more functional for identifying potential issues and can contribute to management and policy improvements within a fishery. The only weak point is the establishment of reference thresholds, especially for poorly studied fisheries. It is obvious that, if sustainability indexes are available, temporal comparisons can be made, otherwise the thresholds should be set according to the characteristics of the fishery or similar fisheries.

Beyond the opposition between large-scale and small-scale fisheries in terms of sustainability [29], this work shows the differences in sustainability that may exist within a small-scale fishery. In fact, if fishing practices are not homogenous within a fishery, differences in terms of sustainability may occur. It is important to have access to efficient tools to identify the potential issues and implement appropriate management policies, as in general the stocks targeted are the same for all the production systems and the unsustainable practices of a few may impact the entire fishery.

Regarding sustainability, there are no outstanding good or bad performance ratings for the French Guiana small-scale production systems. The present study shows that the analyzed fishery systems are not only far from ideal, but also far from unsustainable. Within these "sustainability" margins, FSs present different performance levels: (i) FSs are more efficient in the ecological field and less in the social one; (ii) FSs with the smallest fleets ("P" and "CC") are the most "sustainable", if their informality is accepted, while "CCA" fleets have the worst results; (iii) A gradient of sustainability appears from the western portion of the coast to the eastern portion.

In view of the overall results, and in terms of a management plan, improvements are necessary in order to reach a situation that would enable long-term exploitation. To increase the "sustainability status" of the FSs in French Guiana, progress must be made on several points. Firstly, the rate of discards must be reduced, especially for the "T" and "CCA" fleets. Finding new markets for the low-value discarded species is one solution. Secondly, the coastal fishery should be better structured and the fishers ${ }^{\text {ee }}$ cooperatives more efficient to reduce equipment costs. In addition, to raise the economic value of the product, this fishery should be promoted using an ecolabel system, for example. Thirdly, the selectivity of gears should be increased and trip lengths better monitored. Finally, the fishers ${ }^{\text {ee }}$ education should be improved to enable them to get a better understanding of the issues, which would certainly incite them to improve their fishing practices in a sustainable way and to get more involved in management decisions. Out of all FSs, the "SG_CC" seems to be the least sustainable (even according to a weak sustainability approach). Management of this FS operating in the FrenchBrazilian border area requires the implication of Brazilian stakeholders, as it is in competition for resources with certain Brazilian fleets. Nevertheless, this FS needs facilities (provision of fuel and ice) and new markets. 
Maintaining the fishery and resources monitoring system started in 2006 will lead to progress in attribute scoring and allow Rapfish to be applied within an inter-temporal framework as recently in Garmendia et al. [27]. Another step would be to compare small-scale coastal sustainability with the sustainability of other large-scale fisheries in French Guiana such as the industrial shrimp fishery and the red snapper fishery. The rapid growth of the population, which is expected to double by 2030, raises the issue of fish supply shortages. Cissé et al. [30] show that maintaining the current effort level will not be satisfactory from an ecological, economic, and fish supply point of view. More eco-friendly behaviors must therefore be adopted to guarantee the sustainability of this fishery.

\section{$\underline{\text { Acknowledgements }}$}

This work was carried out with the financial support of the ANR (French National Research Agency) under the ADHOC program, the ERDF (European Regional Development Fund) under the DEPECHE program, the FRB (Fondation Recherche Biodiversité) under the BIOMER project and IFREMER. We thank all the fishermen who agreed to provide economic data as well as all the observers who collected the other fishery data sets each day.

\section{$\underline{\text { References }}$}

[1] Pikitch EK, Santora C, Babcock EA, Bakun A, Bonfil R, Conover DO, Dayton P, Doukakis P, Fluharty D, Heneman B, Houde ED, Link J, Livingston PA, Mangel M, McAllister MK, Pope J, Sainsbury KJ. Ecosystem-based fishery management. Science 2004; 305 (5682): 346-347.

[2] Worm B, Hilborn R, Baum JK, Branch TA, Collie JS, Costello C, Fogarty MJ, Fulton EA, Hutchings JA, Jennings S, Jensen OP, Lotze HK, Mace PM, McClanahan TR, Minto C, Palumbi SR, Parma AM, Ricard D, Rosenberg AA, Watson R, Zeller D. Rebuilding global fisheries. Science 2009; 325 (5940): 578-585.

[3] FAO. Code of Conduct for Responsible Fisheries; 1995.

[5] Salas S, Chuenpagdee R, Seijo JC, Charles A. Challenges in the assessment and management of small-scale fisheries in latin america and the Caribbean. Fisheries Research 2007; 87 (1): 5-16.

[5] Chuenpagdee R. Small Scale Fisheries. Contemporary Visions, Eburon Publishers; 2011.

[6] Guyader O, Berthou P, Koutsikopoulos C, Alban F, Demanéche S, Gaspar M, Eschbaum R, Fahy E, Tully O, Reynal L, Curtil O, Frangoudes K, Maynou F. Small scale fisheries in europe: A comparative analysis based on a selection of case studies. Fisheries Research 2013; 140(0): 1-13.

[7] Leadbitter D, Ward TJ. An evaluation of systems for the integrated assessment of capture fisheries. Marine Policy 2007; 31 (4): 458 - 469. 
[8] Garcia S, Allison EH, Andrew N, Béné C, Bianchi G, De Graaf G, Kalikoski D, Mahon R, Orensanz L. Towards integrated assessment and advice in small-scale fisheries: principles and processes. FAO fisheries and aquaculture technical paper; 515. Rome; 2008.

[9] Pitcher TJ, Preikshot D. A rapid appraisal technique to evaluate the sustainability status of fisheries. Fisheries Research 2001; 49 (3): 255-270.

[10] Andriguetto-Filho JM, Krul R, Feitosa S. Analysis of natural and social dynamics of fishery production systems in Parana, Brazil: implications for management and sustainability. Journal of Applied Ichthyology 2009; 25 (3): 277-286.

[11] Castello JP, Sunye PS, Haimovici M, Hellebrandt D. Fisheries in southern Brazil: a comparison of their management and sustainability. Journal of Applied Ichthyology 2009; 25

(3): 287-293.

[12] Isaac VJ, Santo RVE, Bentes B, Fredou FL, Mourao KRM, Fredou T. An interdisciplinary evaluation of fishery production systems off the state of Para in north Brazil. Journal of Applied Ichthyology 2009; 25 (3): 244-255.

[13] Lessa RP, Monteiro A, Duarte-Neto PJ, Vieira AC. Multidimensional analysis of fishery production systems in the state of Pernambuco, Brazil. Journal of Applied Ichthyology 2009; 25 (3): 256-268.

[14] Martins AS, Dos Santos LB, Pizetta GT, Monjardim C, Doxsey JR. Interdisciplinary assessment of the status quo of the marine fishery systems in the state of Espirito Santo, Brazil, using rapfish. Journal of Applied Ichthyology 2009; 25 (3): 269-276.

[15] Neumayer E. Weak Versus Strong Sustainability: Exploring the Limits of Two Opposing Paradigms. Edward Elgar, Cheltenham, UK, Northampton, MA, USA; 1999.

[16] Daly HE. Toward some operational principles of sustainable development. Ecological Economics 1990; 2 (1): 1-6.

[17] Daly HE. Beyond Growth. Boston: Beacon Press; 1996.

[18] Chaboud C, Vendeville P, Blanchard F, Viera A. Bio-economic modelling as an integrative tool assess the dynamics of fisheries facing global economic environmental changes: the example of the french guyana shrimp fishery, in: Coping with global ,change in marine social-ecological systems: programme and abstracts; 2008.

[19] Leopold M. Guide des poissons de mer de Guyane. Ifremer; 2004.

[20] Bellail R, Dintheer C. La pêche maritime en Guyane Française, flottilles et engins de Pêche. Tech rep. Ifremer; 1992.

[21] Levrel A. Estimation de la pêche illégale étrangère en Guyane Française. Tech rep. Ifremer; 2012. 
[22] Van Iseghem S, Quillérou E, Brigaudeau C, Macher C, Guyader O, Daurès F. Ensuring representative economic data: survey data-collection methods in France for implementing the common fisheries policy. ICES Journal of Marine Science: Journal du Conseil 2011; 68 (8): $1792-1799$.

[23] EC. Commission decision adopting a multi-annual community programme pursuant to council regulation (ec) no 199/2008. Official journal of the European Union, 160/51. 52413 pp; 2008.

[24] Kavanagh P, Pitcher T. Implementing microsoft excel software for rapfish: A technique for the rapid appraisal of fisheries status. Tech Rep 12(2), Fisheries Centre Research Reports; 2004.

[25] Pitcher TJ, Kalikoski D, Short K, Varkey D, Pramod G. An evaluation of progress in implementing ecosystem-based management of fisheries in 33 countries. Marine Policy 2009; 33 (2): $223-232$.

[26] Tesfamichael D, Pitcher T. Multidisciplinary evaluation of the sustainability of red sea fisheries using rapfish. Fisheries Research 2006; 78 (2-3): 227-235.

[27] Garmendia E, Prellezo R, Murillas A, Escapa M, Gallastegui M. Weak and strong sustainability assessment in fisheries. Ecological Economics 2010; 70 (1): 96-106.

[28] Baeta F, Pinheiro A, Corte-Real M, Costa JL, De Almeida PR, Cabral H, Costa MJ. Are the fisheries in the tagus estuary sustainable? Fisheries Research 2005; 76 (2); 243-251.

[28] Baeta F, Pinheiro A, Corte-Real M, Costa JL, De Almeida PR, Cabral H, Costa MJ. Are the fisheries in the tagus estuary sustainable? Fisheries Research 2005; 76 (2); 243-251.

[29]Jacquet J, and Pauly D. Funding priorities: big barriers to small-scale fisheries. Conservation Biology 2008; 22:832-835.

[30] Cissé AA, Gourguet S, Doyen L, Blanchard F, Péreau JC. A bio-economic model for the ecosystem-based management of the coastal fishery in French Guiana. Environment and Development Economics 2013; 18: 245-269. 


\begin{tabular}{|c|c|c|c|c|}
\hline Landing sites & Vessel types & $\begin{array}{c}\text { Number of } \\
\text { vessels actives } \\
\mathbf{( 2 0 1 0 )}\end{array}$ & Acronyms & Code \\
\hline Saint Laurent & Canot Créole & 8 & SL_CC & 1 \\
\hline Awala-Yalimapo & Pirogue & 23 & AY_P & 2 \\
\hline Sinnamary & Canot Créole Amélioré & 17 & SI_CCA & 3 \\
\hline Sinnamary & Canot Créole & 3 & SI_CC & 4 \\
\hline Kourou & Canot Créole Amélioré & 3 & K_CCA & 5 \\
\hline Kourou & Canot Créole & 8 & K_CC & 6 \\
\hline Cayenne & Tapouille & 6 & C_T & 7 \\
\hline Cayenne & Canot Créole Amélioré & 17 & C_CCA & 8 \\
\hline Cayenne & Canot Créole & 15 & C_CC & 9 \\
\hline Montjoly & Canot Créole Amélioré & 16 & M_CCA & 10 \\
\hline Saint Georges & Canot Créole & 15 & SG_CC & 11 \\
\hline
\end{tabular}

Table 1 The 11 Fishing Systems.

\begin{tabular}{|c|c|c|c|c|}
\hline & Good & Bad & Notes & Sources \\
\hline \multicolumn{5}{|l|}{ Ecological analysis } \\
\hline $\begin{array}{l}\text { Recruitement } \\
\text { variability }\end{array}$ & 0 & 10 & $\begin{array}{l}\text { Estimated by the production variability from } 2005 \text { to } \\
2009 \text { (coefficient of variability) : low }<20 \%(0-1) \text {; } \\
\text { medium } 20-60 \%(2-5) \text {; high } 60-100 \%(6-8) \text {; very high } \\
>200 \%(9-10)\end{array}$ & $\begin{array}{l}\text { Standard } \\
\text { attributes }\end{array}$ \\
\hline Size of fish & 0 & 10 & $\begin{array}{l}\text { Has average fish size landed reduced in past } 5-10 \\
\text { years; no or very little }(0-1) \text {; a gradual change }(2-5) \text {; a } \\
\text { rapid large change }(6-8) \text {, major rapid reduction }(9-10) \text {. }\end{array}$ & $\begin{array}{l}\text { Standard } \\
\text { attributes }\end{array}$ \\
\hline Discards & 0 & 10 & $\begin{array}{l}\text { Percentage of target catch : low } 0-10 \%(0-1) \text {; medium } \\
10-40 \%(2-5) \text {; high }>40 \%(6-8) \text {; very high }>100 \%(9- \\
10)\end{array}$ & $\begin{array}{l}\text { Standard } \\
\text { attributes }\end{array}$ \\
\hline Trophic level & 10 & 0 & Average of trophic level of species in catch $\times 2$. & $\begin{array}{l}\text { Pitcher and } \\
\text { Preikshot } \\
(2001)\end{array}$ \\
\hline $\begin{array}{l}\text { Change in trophic } \\
\text { level }\end{array}$ & 0 & 10 & $\begin{array}{l}\text { Is trophic level of species in catch decreasing during } \\
\text { the last } 4 \text { years: no or very little }(0-2) \text {; a gradual } \\
\text { change }(3-5) \text {; a rapid large change }(6-8) \text {, major rapid } \\
\text { reduction }(9-10) \text {. }\end{array}$ & $\begin{array}{l}\text { Pitcher and } \\
\text { Preikshot } \\
\text { (2001) }\end{array}$ \\
\hline \multicolumn{5}{|l|}{ Economic analysis } \\
\hline Average wage & 10 & 0 & $\begin{array}{l}\text { Do fishers make more or less than the average } \\
\text { person? Much less }(0-2) \text {; less }(3-4) \text {; the same }(5-6) \text {; } \\
\text { more }(7-8) \text {; much more }(9-10)\end{array}$ & $\begin{array}{l}\text { Standard } \\
\text { attributes }\end{array}$ \\
\hline Profitability & 10 & 0 & $\begin{array}{l}\text { Annual profit rate; very loss-making: }<-10 \%(0-2) \text {; } \\
\text { unprofitable: }-10 \text { to } 0 \%(3-4) \text {; profitable } 0-20 \%(5-7) \text {; } \\
\text { very profitable }>20 \%(8-10)\end{array}$ & \\
\hline Other income & 0 & 10 & $\begin{array}{l}\text { In this fishery, fishing is mainly: casual }(0-2) \text {, part- } \\
\text { time (3-5); seasonal (6-8); full-time }(9-10)\end{array}$ & $\begin{array}{l}\text { Standard } \\
\text { attributes }\end{array}$ \\
\hline Sector employment & 0 & 10 & $\begin{array}{l}\text { Employment in formal sector of this fishery: }<10 \% \\
(0-3) ; 10-20 \%(4-7) ;>20 \%(8-10) ;>30 \% \text { [compared }\end{array}$ & $\begin{array}{l}\text { Standard } \\
\text { attributes }\end{array}$ \\
\hline
\end{tabular}

\footnotetext{
${ }^{5}$ Standard attributes refers to those revised by the Rapfish Group, Fisheries Centre, UBC and downloaded in July 2011 from the website, ,http://www.rapfish.orge
} 


\begin{tabular}{|c|c|c|c|c|}
\hline & & & to all the other fisheries at the same scale of analysis]. & \\
\hline Market & 0 & 10 & $\begin{array}{l}\text { Market is principally: local (0-2); regional/local (3- } \\
\text { 5); national/regional (6-8); local/international (9-10) }\end{array}$ & $\begin{array}{l}\text { Standard } \\
\text { attributes }\end{array}$ \\
\hline Subsidy & 0 & 10 & $\begin{array}{l}\text { Are subsidies (including hidden subsidies) provided } \\
\text { to support the fishery? no (o-2); somewhat (3-4); } \\
\text { large subsidies (5-6); heavily reliant (7-8); almost } \\
\text { completely reliant on subsidies (9-10). }\end{array}$ & $\begin{array}{l}\text { Standard } \\
\text { attributes }\end{array}$ \\
\hline Average catch price & 10 & 0 & $\begin{array}{l}(€ \text { per kg): very low } 0-2 €(0-2) ; \text { low } 2-2.5 €(3-4) \text {; } \\
\text { medium } 2.5-3 €(5-6) ; 3-4 €(7-8) \text {; very high }>4 €(9- \\
10)\end{array}$ & $\begin{array}{l}\text { Isaac et al } \\
\text { (2009) }\end{array}$ \\
\hline $\begin{array}{l}\text { Average production } \\
\text { per year }\end{array}$ & 10 & 0 & $\begin{array}{l}\text { Relative weight of the landings compared to all FPS } \\
\text { landings: }<10 \%(0-3) ; 10-20 \%(4-7) ;>20(8-10)\end{array}$ & $\begin{array}{l}\text { Isaac et al } \\
(2009)\end{array}$ \\
\hline Cost of equipment & 0 & 10 & $\begin{array}{l}\text { Percentage of the equipment costs in the total } \\
\text { income: } 0-10 \%(0-2) ; 10-20 \%(3-4) ; 20-30 \%(5-6) \text {; } \\
30-40 \%(7-8) ;>40 \%(9-10)\end{array}$ & $\begin{array}{l}\text { Isaac } \text { et al } \\
\text { (2009) }\end{array}$ \\
\hline $\begin{array}{l}\text { Dependence on } \\
\text { middlemen }\end{array}$ & 0 & 10 & $\begin{array}{l}\text { Dependence rate (part of the income with middlemen } \\
\text { on the total income): } 0 \%(0) \text { to } 100 \%(10)\end{array}$ & $\begin{array}{l}\text { Isaac } \text { et al } \\
(2009)\end{array}$ \\
\hline \multicolumn{5}{|l|}{ Social analysis } \\
\hline Education level & 10 & 0 & $\begin{array}{l}\text { Education level compared to population average: } \\
\text { much lower(0-3); lower (4-6); close(7-8); superior(9- } \\
\text { 10) }\end{array}$ & $\begin{array}{l}\text { Pitcher and } \\
\text { Preikshot } \\
(2001)\end{array}$ \\
\hline Conflict status & 0 & 10 & $\begin{array}{l}\text { Level of conflict with other sectors: almost none, } 0- \\
10 \%(0-2) ; \text { some, } 11-40 \%(3-5) ; \text { lots } 41-60 \%(6-8) ; a \\
\text { great amount } 61-100 \%(9-10)\end{array}$ & $\begin{array}{l}\text { Standard } \\
\text { attributes }\end{array}$ \\
\hline Kin participation & 10 & 0 & $\begin{array}{l}\text { Do kin sell and/or process fish? Almost none, } 0-10 \% \\
(0-2) \text {; a few relatives } 10-40 \%(3-5) \text {; some relatives (6- } \\
8 \text { ); fishery is mainly kin }(9-10)\end{array}$ & $\begin{array}{l}\text { Isaac } \text { et al } \\
(2009)\end{array}$ \\
\hline Origin of fishermen & 0 & 10 & $\begin{array}{l}\text { Local }(0-2) ; \text { local/regional }(3-4) \text {; border country }(5-7) \\
\text {; distant country }(8-10)\end{array}$ & $\begin{array}{l}\text { Isaac } \text { et al } \\
(2009)\end{array}$ \\
\hline Healthcare & 0 & 10 & $\begin{array}{l}\text { Evaluated according to distance from major health } \\
\text { centers: } 0-20 \mathrm{~km}(0-3) ; 21-50 \mathrm{~km}(4-6) ; 51-100 \mathrm{~km}(6- \\
8) ;>100 \mathrm{~km}(9-10)\end{array}$ & $\begin{array}{l}\text { Castello et al } \\
\text { (2009) }\end{array}$ \\
\hline Residence quality & 10 & 0 & $\begin{array}{l}\text { Poor :Fishers live in the boat (0) to Excellent: House } \\
\text { with all commodities (10) }\end{array}$ & $\begin{array}{l}\text { Castello et al } \\
(2009)\end{array}$ \\
\hline Place of residence & 10 & 0 & $\begin{array}{l}\text { Isolated village (0-2); village(3-4); town(5-7); large } \\
\text { town }(8-10)\end{array}$ & \\
\hline \multicolumn{5}{|l|}{$\begin{array}{l}\text { Technological } \\
\text { analysis }\end{array}$} \\
\hline Trip length & 0 & 10 & $\begin{array}{l}\text { Average days at sea per fishing trip: } 1 \text { or less }(0-1) ; 2- \\
4 \text { days }(2-4) ; 5-8 \text { days }(5-6) ; 8-10 \text { days }(7-8) ; \text { more } \\
\text { than } 10 \text { days }(9-10) \text {. }\end{array}$ & $\begin{array}{l}\text { Standard } \\
\text { attributes }\end{array}$ \\
\hline Pre-sale processing & 10 & 0 & $\begin{array}{l}\text { Processing before sale, [e.g., gutting, filleting, salting] } \\
\text { none (0-2); some (3-5); a lot (6-8); a great deal }(9-10)\end{array}$ & $\begin{array}{l}\text { Standard } \\
\text { attributes }\end{array}$ \\
\hline Selective gear & 10 & 0 & $\begin{array}{l}\text { Device(s) and/or handling of gear to increase } \\
\text { selectivity and reduce bycatch? Very little }(0-2) \text {; some } \\
\text { (3-5); a lot (6-8); a great amount (9-10) }\end{array}$ & $\begin{array}{l}\text { Standard } \\
\text { attributes }\end{array}$ \\
\hline Vessel size & 0 & 10 & $\begin{array}{l}\text { Average length of vessels: }<5 \mathrm{~m}(0-2) ; 5-9 \mathrm{~m}(3-4) ; 10- \\
12 \mathrm{~m}(5-6) ; 13-20 \mathrm{~m}(7-8) ;>20 \mathrm{~m}(9-10)\end{array}$ & $\begin{array}{l}\text { Standard } \\
\text { attributes }\end{array}$ \\
\hline Power Source & 0 & 10 & $\begin{array}{l}\text { any (0); <30 HP(1-3); } 30-60 \mathrm{HP}(4-5) ; 60-100 \mathrm{HP}(6- \\
7) ; 100-140 \mathrm{HP}(8-9) ;>140 \mathrm{HP}(10)\end{array}$ & $\begin{array}{l}\text { Castello et al } \\
\text { (2009) }\end{array}$ \\
\hline
\end{tabular}

Table 2. List of attributes and scoring framework. 


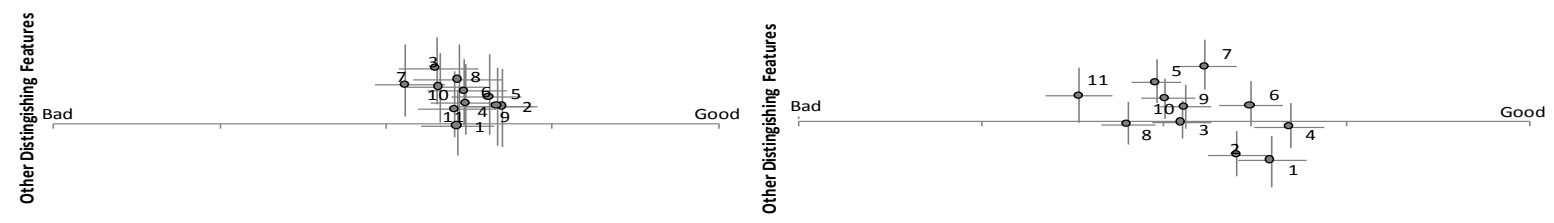

Social performance

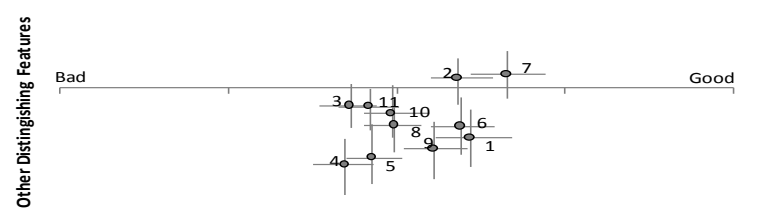

Technological performance

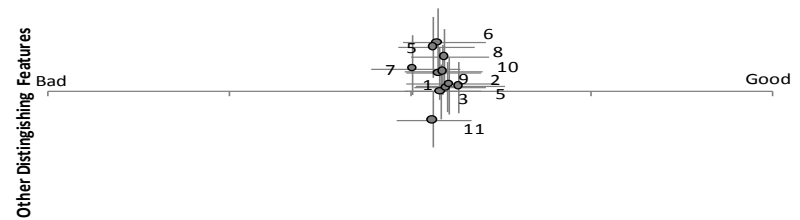

Fig- 1.Two-dimensional ordination plots from the MDS analyses; horizontal axis indicates performance score (from 'Bad' to 'Good'); Verticales position relates to the other distinguishing features; Thin lines represent the inter-quartile (IQ) ranges from 500 Monte Carlo simulations; See table 1 for fishery codes.
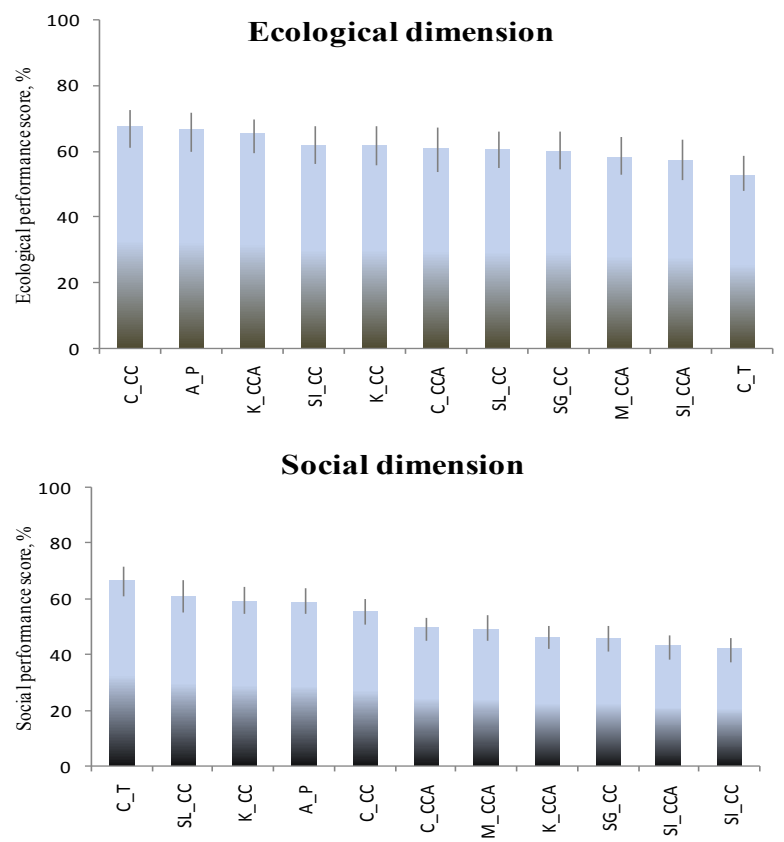

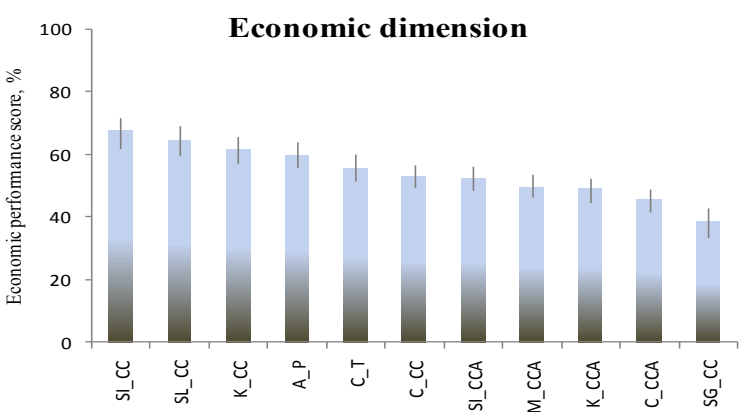

Technological dimension

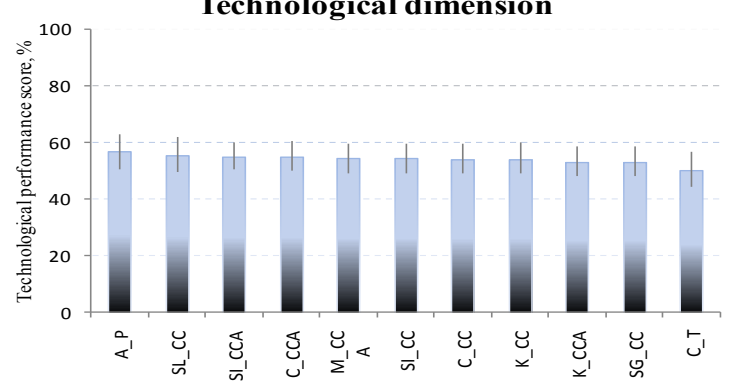

Fig- 2. Sustainability performance rating for French Guyana coastal fisheries in four evaluation fields. Fisheries are shown in order of performance rating from left to right; Thin lines represent the inter-quartile (IQ) ranges from $\mathbf{5 0 0}$ Monte Carlo simulations; See table 1 for fishery codes. 


\begin{tabular}{|c|c|c|}
\hline Evaluation fields & Kurkal's stress & RSQ \\
\hline Ecological & 0.200 & 0.940 \\
\hline Economic & 0.174 & 0.912 \\
\hline Social & 0.208 & 0.903 \\
\hline Technological & 0.282 & 0.864 \\
\hline
\end{tabular}

Table 3 Kurkal's stress and RSQ for the different evaluation fields.

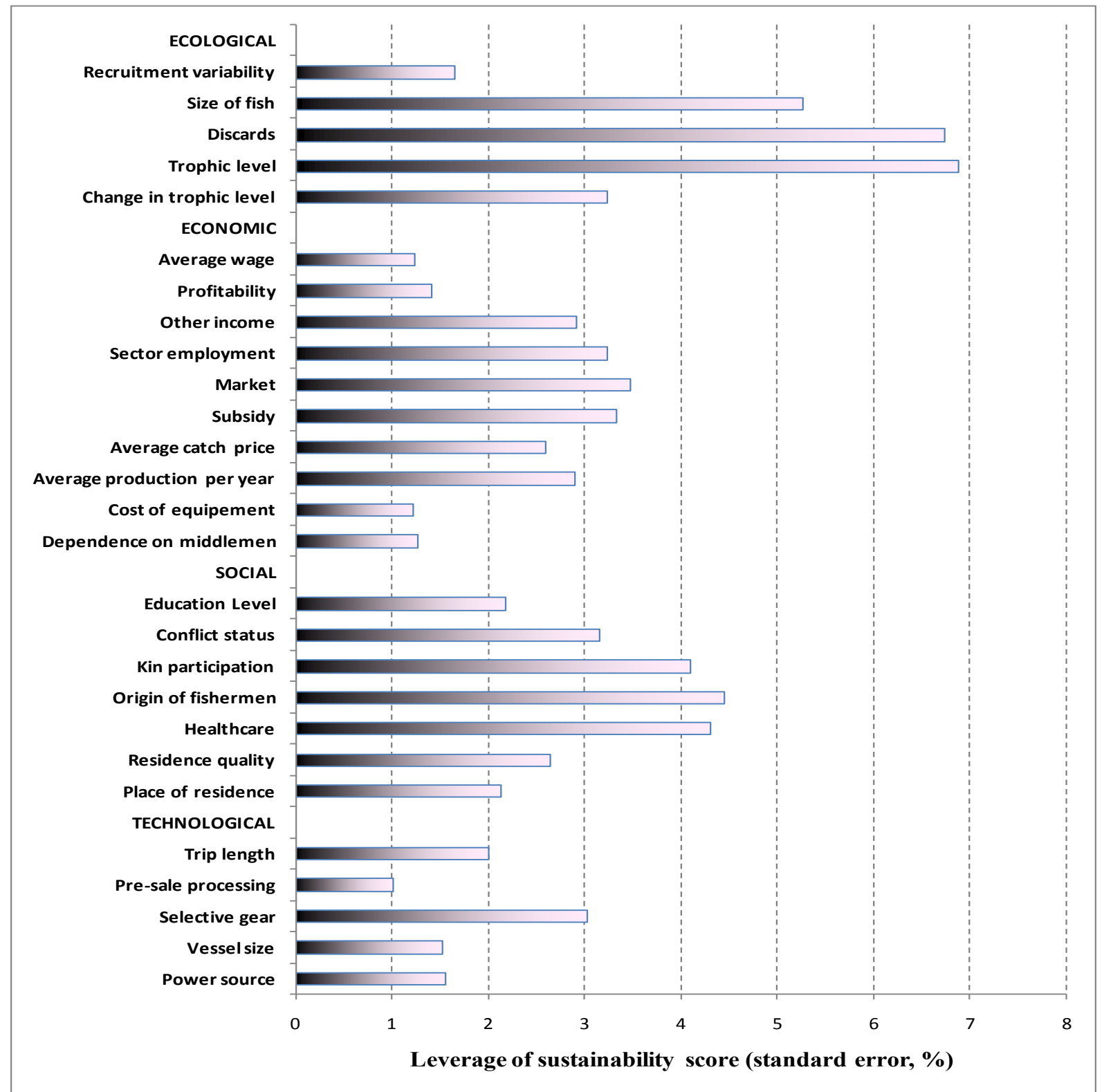

Fig-3. Leverage of attributes, given by the mean standard error (S.E), in their respective evaluation field. 


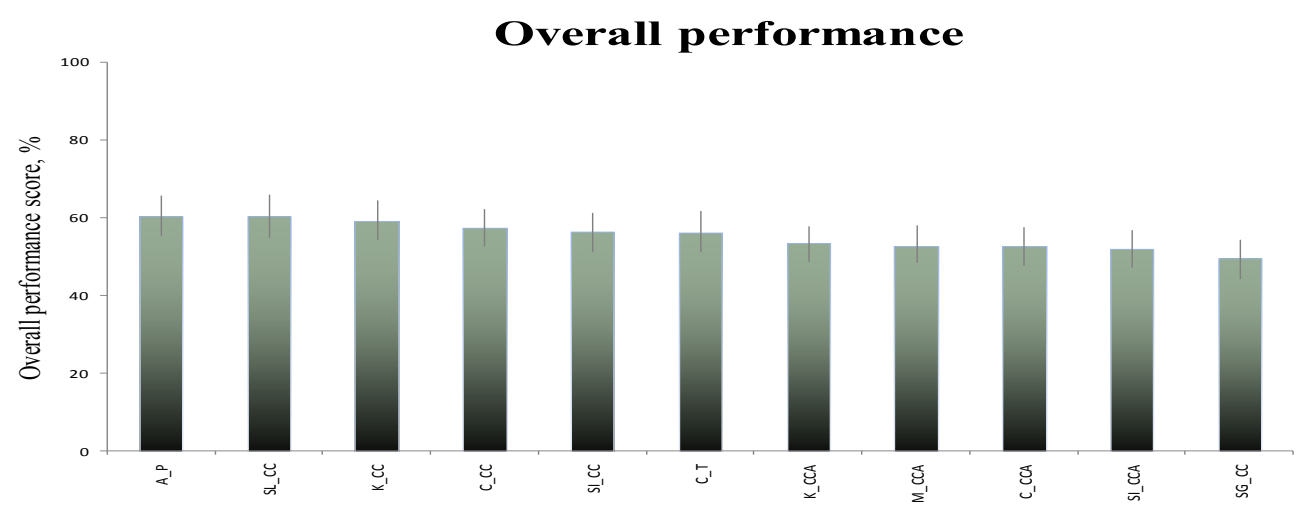

Fig-4. Overall French Guyana coastal fishery systems performance; Thin lines represent the inter-quartile (IQ) ranges from $\mathbf{5 0 0}$ Monte Carlo simulations; See table 1 for fishery codes.
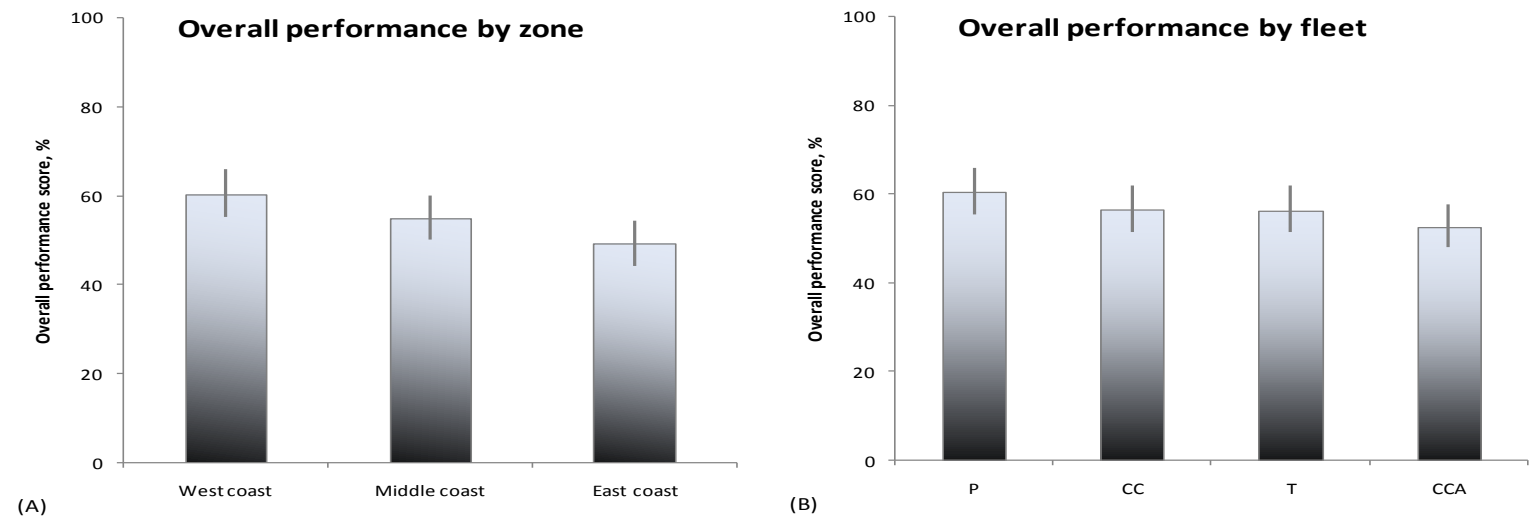

Fig-5. Overall sustainability performance. (A) by Zone. (B) By fleet. ' $P$ ' stands for 'Pirogue', 'CC' for 'Canot créole', 'T' for 'Tapouille' and 'CCA' for 'Canot créole amélioré'. 


\begin{tabular}{|c|c|c|c|c|c|c|}
\hline & & \multicolumn{4}{|c|}{ Strong sustainability index } & Weak sustainability index \\
\hline FPS & Code & Ecological & Economic & Social & Technological & Mean \\
\hline SL_CC & 1 & 60,6 & 64,6 & 60,8 & 55,4 & 60,3 \\
\hline A_P & 2 & 66,5 & 59,8 & 58,9 & 56,7 & 60,5 \\
\hline SI_CCA & 3 & 57,4 & 52,4 & 43,0 & 55,0 & 51,9 \\
\hline SI_CC & 4 & 61,8 & 67,7 & 42,1 & 54,2 & 56,5 \\
\hline K_CCA & 5 & 65,3 & 48,9 & 46,2 & 53,2 & 53,4 \\
\hline K_CC & 6 & 61,6 & 61,8 & 59,3 & 53,8 & 59,1 \\
\hline C_T & 7 & 52,8 & 55,6 & 66,2 & 50,3 & 56,2 \\
\hline C_CCA & 8 & 60,7 & 45,5 & 49,5 & 54,7 & 52,6 \\
\hline C_CC & 9 & 67,3 & 53,0 & 55,3 & 54,0 & 57,4 \\
\hline M_CCA & 10 & 57,9 & 49,6 & 49,1 & 54,6 & 52,8 \\
\hline SG_CC & 11 & 60,1 & 38,8 & 45,8 & 53,1 & 49,5 \\
\hline
\end{tabular}

Table 4 Scores of each fishery production system (FPS) according to the Rapfish method. Bolded characters indicate FPS that are not sustainable according to the strong sustainability position while these FPS are sustainable considering the weak sustainability position.

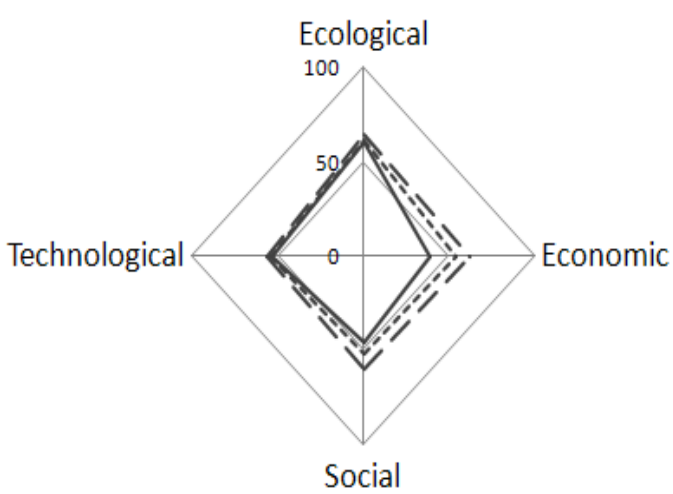

(A) - West coast -----・ Middle coast —_East coast

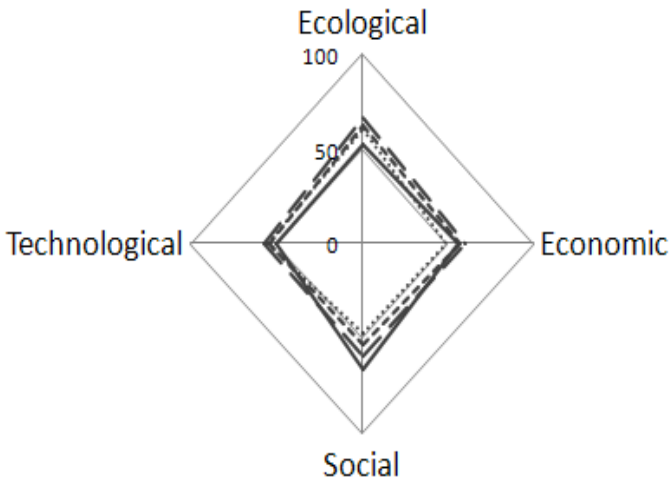

(B)

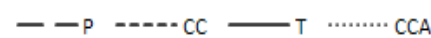

Fig-6. Kite representation of the evaluation of French Guyana coastal fishery system grouped by zone (A) and fleet (B). 